\title{
Implementation of logistic approaches in forming the agricultural export strategy in Ukraine
}

\section{Tetiana Larina, Andrii Kravcov, Natalija Berezhnaja, Olesya Kutiya, Kateryna Fenenko}

Kharkiv Petro Vasylenko National Technical University of Agriculture, 44, Alchevskikh Street, Kharkiv, 61002 Ukraine

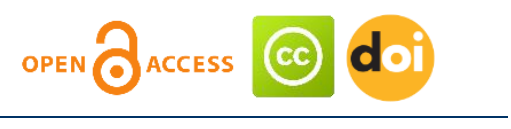

\section{Article history:}

Received:February 25, 2019

1st Revision: March 05, 2019

Accepted: April 29, 2019

\section{DOI:}

10.14254/jsdtl.2019.4-1.2

\begin{abstract}
The work is aimed at analysing the state and prospects of implementing the export potential of the agrarian sector of Ukraine, the structure of which is based on the principles of transition from the abstract to the concrete. The study begins with the definition of factors that shape the export opportunities of the agrarian sector, namely: the quality of the factors of agricultural production (objects of labour, means of labour); the branch structure of agricultural production; the state of the systems of certification and quality control of export products; the diversification of markets; the access to financial resources; the level of the marketing support of export; the mechanisms of the realization of the state export policy; the state of development of agro-logistics. It has been proved that in the short term, the production components are not decisive in the processes of using and expanding the existing export potential of the national agrarian sector. In the modern conditions the state of logistics infrastructure is coming to the forefront. In the general problem of agro-logistics, the following levels are distinguished: micro-, meso-, macro-, and supranational. In each of them we have identified "the bottlenecks" of the process of building up export potential from the point of view of agro-logistics. The ways of increasing the export potential of the agrarian sector in Ukraine have been proposed. These include: the development of container transportation sphere; the creation of effective mechanisms for directing funds of united territorial communities for the development of regional logistics infrastructure; the reform of Ukrzaliznytsia (JSC “Ukrainian Railways"); the development of alternative variants of supply chains by improving the infrastructure of the automobile and river transport; the expansion of the representation of Ukraine in the world governmental and non-governmental organizations in order to protect the national trade interests; the formation of the system
\end{abstract}

Corresponding author: Tetiana Larina

E-mail: ltf-2010@ukr.net 
of training personnel capable of adapting to changing market conditions.

Keywords: logistic approach, agrarian export strategy, export potential, agro-logistics, agrarian infrastructure, supply chain.

\section{Introduction}

Within the framework of economic policy in Ukraine, the agrarian and export strategy takes up one of the key places. There are objective reasons for this. Thus, in the 2016-2017 marketing year, Ukraine occupied the first place in the world rating of sunflower seeds producers and exporters of sunflower oil, the fourth place among the world exporters of corn, and the sixth - of wheat. According to the results of 2016-2017, the agrarian share in the structure of the national export amounted to 42$46 \%$, providing $30 \%$ of foreign currency incomes. In favour of the prospects of agrarian export strategy in the long run the expert assessment of the development of the world market of agro-products speaks, where the growth of demand is recognized as the decisive trend. Per capita food consumption over the past 20 years has increased by $10 \%$ (in terms of energy equivalent).

In the conditions of strengthening Ukraine's integration aspirations, it is the agrarian business and all its components that serve as one of the key elements in the formation of partnership relations. Currently, Ukraine is among the TOP-10 world producers of grain crops and annually increases its potential. This, of course, points to the potential of our country's emergence as a leader in the global trading arena. At the same time, the agrarian export strategy is now soundly recognized as one of the priority directions of the overall economic development of the country as a whole.

A large number of scientific works by domestic authors is devoted to the study of the problems associated with the formation of the export strategy of products of ACP (agriculture production) (in the majority - they are grain crops). Thus, in article Petrenko and Davidovich (2017) the current state of the development of the agrarian products market of Ukraine and its possibilities in the modern world economic space have been analysed. The factors contributing to the development of the country's agrarian economy and the factors that hinder the growth of production and export growth are considered in article Lazareva \& Vakar (2019). Radchenko and Shavalyuk (2017) investigated the state of the development of the agro-food market as a component of foreign economic activity of Ukraine and conducted a systematic analysis of the dynamics of export and import of the produce structure in relations between Ukraine and the EU. Article (Zinchuk, 2015) has proved the existence of organizational, socio-economic and institutional obstacles that have been identified at the transitional stage of implementation of the FTA Agreement in the agrarian sector of the economy. Dudar (2015) considers the main directions of the integration of the agrarian sector of Ukraine's economy into the European Union's space under the conditions of functioning of the free trade zone. A systematic analysis of the produce structure and the dynamics of Ukrainian export of agro-food products to the EU countries after Ukraine's entry into the World Trade Organization has been carried out. The main components of the state regulation of the agrarian sector of the economy, which are associated with the improvement of economic policy in order to strengthen the competitive positions of rural goods producers in the market of agro-food produce, are presented in (Dudar, 2017).

From the analysis of the above publications it is clear that the issues of agrarian business development and the formation of the agrarian export strategy in Ukraine are relevant, but the impact of agro-logistics on the processes of the export of agricultural produce has received insufficient attention, which requires further research, namely, the details of the definition of the "bottlenecks" of the process of increasing the export potential.

Is to identify the "bottlenecks" of the process of increasing the export potential at each level of the chain "Agrarian Enterprise - Region - State - External Market" through the use of logistic approaches, and on the basis of the analysis data, to formulate proposals on increasing the export potential of the agrarian sector in Ukraine. 


\section{Methodology}

In our opinion, the main factors determining the agrarian export potential of Ukraine are:

- the quality of the factors of production: the objects of labour, the means of labour. The main object of labour in agriculture is land. The modern technologies of its cultivating (non-compliance with the principles of crop rotation, the removal of protective tree-bands, a sharp reduction in the use of natural fertilizers, etc.) lead to depletion of land, reducing its fertility. The level of the technical and technological equipment of processes in agrarian production has an important influence on the performance of agrarian enterprises (Larina, 2016);

- the sectorial structure of agricultural production, which determines the produce nomenclature of the export. So, the EU countries are one of the strategic partners of Ukraine in the agricultural products trade. At the same time, they introduce quotas for the duty-free export of goods to their territory. Analysing the exhaustion of the indicated quotas, we can see that for some types of products they have been realized by the end of 2019 (grain, corn, etc.), and for some they are not exhausted at all (livestock products). Consequently, it can be concluded that improving the sectorial structure of agrobusiness production can significantly affect the macroeconomic situation in Ukraine by means of expanding its export potential;

- the state of the systems of certification and quality control of export products against the background of a significant increase in the requirements for consumer and environmental characteristics in a number of countries with a priority focus group for Ukraine;

- the diversification of markets. Today, India, Egypt, China, the Netherlands, Spain, and the EU countries are among the main partner countries of Ukraine for the export of agrarian products. The largest impetus for the national ACP was given by the Middle East market during the food crisis. Under the current conditions, the Asian markets may be the driving forces behind the national agro-export, in particular China, Pakistan, and Indonesia. In the stated countries there is a constant increase in the population in the realities of unmet needs for agricultural produce;

- the access to financial resources;

- the level of marketing support for the export;

- the mechanisms of realization of the state export policy;

- the state of the development of agrarian logistics (capacity for storage, transport infrastructure). The competitiveness of national companies in the world market is largely due to the ability to deliver products to the final consumer in due time and in good quality.

\section{Results}

Regarding the physical volume of crop production, in spite of the effect of adverse factors, we have an increase in production volumes. According to Ukrderzhstat (State Statistics Service of Ukraine), the grain yield in Ukraine has had a tendency to increase, since 1999 more than two times - from 20 hundredweight/ha to 46.1 hundredweight/ha in 2016 (Fig. 1). The number of areas under grain and legume crops varies in small limits and has a general tendency to increase (Fig. 2).

In the short term, the production components are not decisive in the processes of using and expanding the existing export potential of the national agrarian sector. So, the foremost among the restraining factors is the state of logistics infrastructure, low efficiency of completion and transportation of products (Vojtov, Berezchnaja, Kravcov \& Volkova, 2018).

Kapitska and Udovenko (2018) note that the agricultural potential of Ukraine is high, but it is largely underexploited. The main problems of agricultural development are:

- the limited access to the financial resources of agricultural producers;

- the absence of a consistent state policy on agricultural development, which leads to the inefficient use of the state funds for supporting agriculture;

- the underdeveloped infrastructure, which leads to an increase in the cost of production, high losses of products during their transportation or storage.

We will consider the problems of agro-logistics on the example of crop production. 
Figure 1: The dynamics of grain yield in Ukraine in 1999-2018

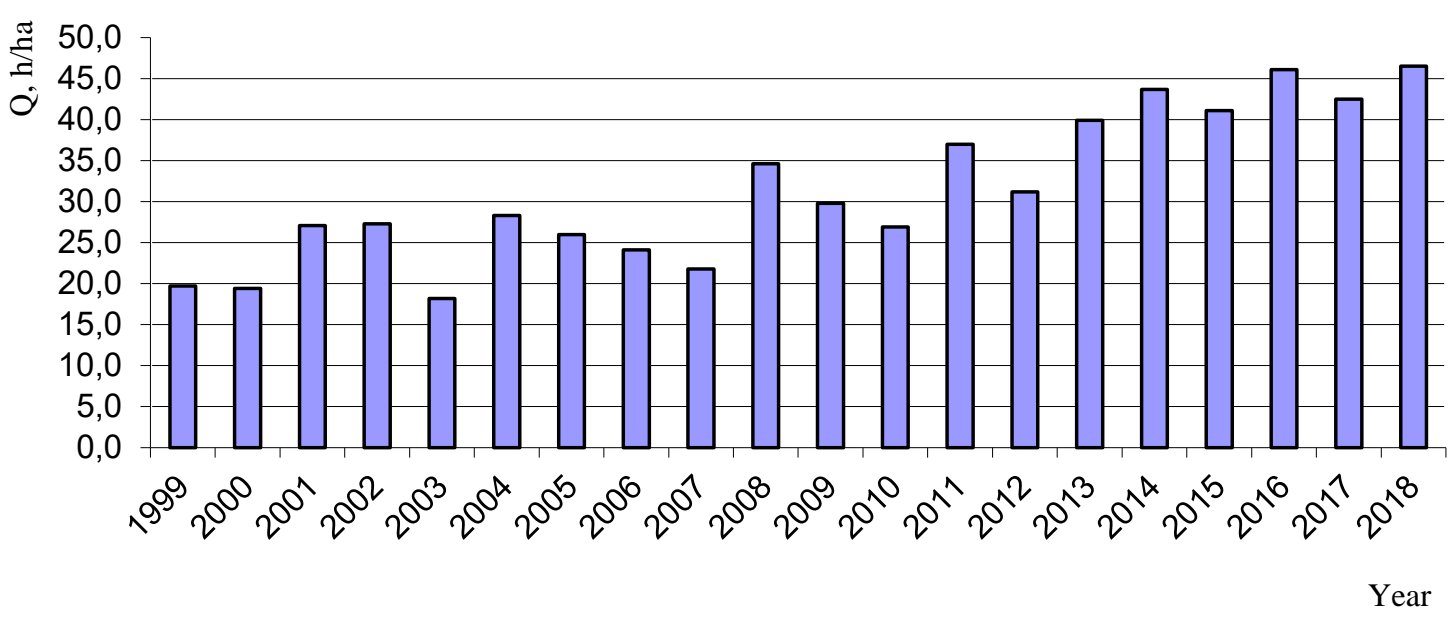

Source: The State Statistics Service of Ukraine (2018).

http://www.ukrstat.gov.ua/operativ/operativ2006/sg/sg_rik/sg_u/rosl_u.html

Figure 2: The dynamics of areas under grain crops and legumes in Ukraine in 1999-2018

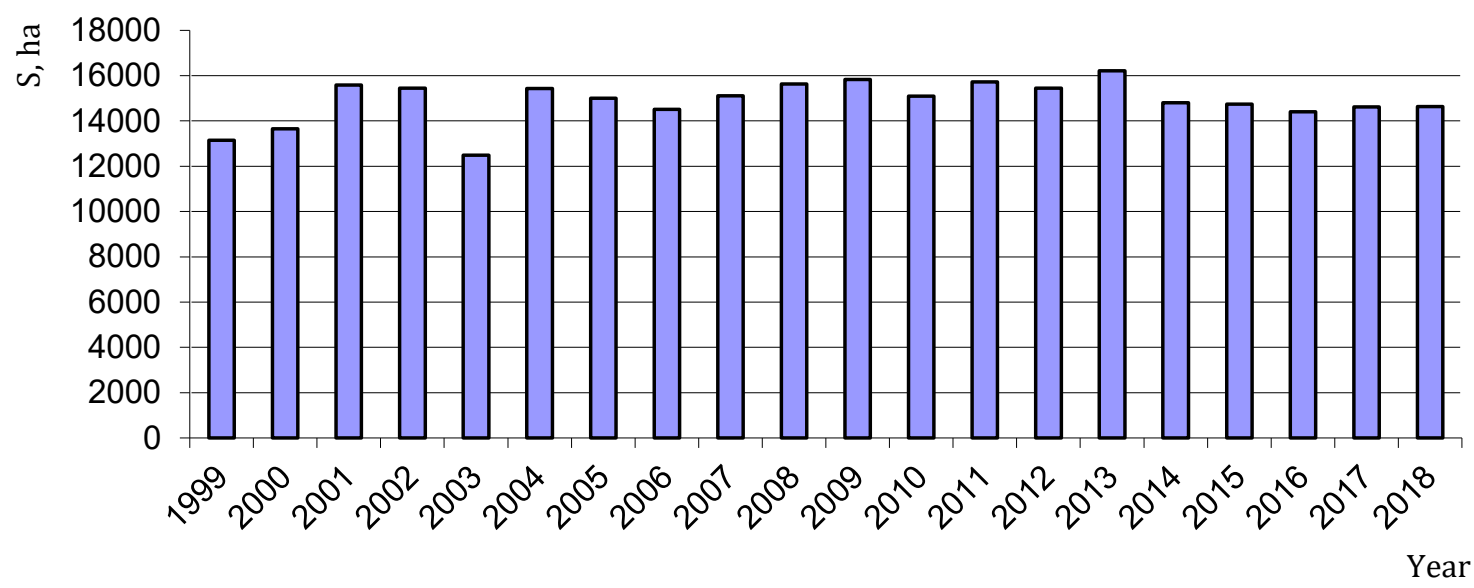

We will distinguish the structural levels in the general problem of agro-logistics:

1. The micro-level.

2. The meso-level.

3. The macro-level.

4. The supranational level.

The micro-level - the agrarian enterprises.

The "bottlenecks" of the logistic process for them are:

- the availability of storage facilities - elevators, granaries. We speak in this case of not only the physical presence of certain objects, but also of the financial ability of farmers to use them. At present, the storage capacity of all linear elevators for storing grain is approximately 50 million tons, and the need for grain and legume crops is about 62-65 million tons, for the oil cultures - about 20 million tons, for the grain milling and processed grain and oilseed crops - about 6-8 million tons. The lack of opportunities to postpone the sale of crops generally excludes agro-business subjects from the export process, since the scale effect does not work (especially for small farms). The largest grain exporter companies include structures of non-agricultural producers, but have logistic storage facilities, such as DPZKU (the state grain corporation), Louis Dryfoods Ukraine Ltd, Bunge Ukraine, and Ambar Export. The possible direction of the development of logistics processes in Ukraine, which reduces the problem of concentration of products of the export party (in this case it is 20 tons, as opposed to 3780 tons of loading 54 wagons-hoppers (the full warehouse), each with a capacity of 70 tons), is the widespread distribution of the container traffic. This is an incentive for the export orientation of farms and expanding the range of customers; 
- the cost of transportation. Today, the costs of moving grain from linear elevators to the Black Sea ports are about 40\% higher than similar costs, for example, in France or Germany, and 30\% in the United States. In fact, the transportation of grain for export is on average $\$ 20$ per ton more expensive than the same services in the European countries. As a result, the domestic producers of grain, according to expert estimates, lose about $\$ 600$ million (Maslak, 2016).

The meso-level - the regions.

At the regional level, the "bottleneck" is the insufficient funding of the development projects for regional logistics infrastructure. In our view, the change in the administrative structure in Ukraine through the formation of United Territorial Communities (UTC) has positive prospects for solving this problem.

UTC receive more financial resources, namely $60 \%$ of the personal income tax, $5 \%$ of the excise tax on the sale of excisable goods, the profit tax on enterprises and municipal enterprises, the property tax (real estate, land, transport), the single tax, $25 \%$ of the environmental tax, the transfers from the state budget (basic grants, educational and medical subventions), the local taxes and fees, the additional state financial support at the expense of the State Fund for the Regional Development, the subventions for socio-economic development, and the subventions in support of infrastructure projects.

It is advisable to invest part of UTC funds in the development of the logistic infrastructure of the designated territories, namely, in the reconstruction (modernization) of the existing elevators, the construction of new (if necessary), the repair and construction of access and trunk roads, and the purchase of specialized movable stock (Muzylyov, Kravcov, Karnayh, Berezhnaja \& Kutiya, 2016).

The macro-level - the state.

The main problem at the state level is the length of internal trans-shipments, due to the mismatch of logistics routes and infrastructure to the modern requirements of the agrarian sector.

Let us trace the classical chain of supply of grain for export: the producer - the elevator - the railroad - the port grain terminals - the seagoing vessels. The connection of the grain crops producer with the elevator happens through the use of the automobile transport, the typical feature of which is a relatively small load-carrying capacity and, consequently, the high cost of transportation. According to the analytical research of Greenco LTD (2017), elevators are able to ship 715 thousand tons per day, the railroad gives wagons for only 117 thousand tons, and the stations in ports can handle 200 thousand tons of cargo, in ports it is possible to unload 182 thousand tons, to load to vessels 250 thousand tons per day. Thus, Ukrzaliznytsia (JSC "Ukrainian Railways") is the "bottleneck", more specifically, there is an insufficient number of grain wagons. The analysis of expert calculations made by the Soufflet Group showed that today the volume of grain exports is 45 million tons. If all this volume is to be transported by the railroad, we will require 18740 wagons, which will work 365 days a year, weekends and holidays included. But in the present situation, when only $67 \%$ are transported by the railroad, 12656 wagons are enough. If grain exports increase to 60 million tons, then the need will be 25 thousand wagons for $100 \%$ export to be done by the railroad. Ukrzaliznytsya (JSC "Ukrainian Railways") has about 14.1 thousand wagons together with the involved ones. Consequently, the lack of wagons-hoppers in the foreseeable future will become critical. In the face of a shortage of investment resources, the attention should be paid to increasing the turnover of the wagon park. A step in this direction may be the removal of artificial time limits for the approval of electronic applications for the transportation. Today the situation is as follows: on the eighth day the system gives a logical error and does not keep an electronic application (Logistics in Ukraine, 2018), which prevents the correct distribution of the movable stock due to the lack of any long-term planning, which leads to increased logistics costs.

Regarding the cost of services by Ukrzaliznytsia (JSC "Ukrainian Railways"), since February 19, 2018, a new procedure for calculating the cost of transportation of goods by the railroad has been in force in Ukraine. This reform led to an increase in the cost of transportation of goods by $17-25 \%$. The participants in the grain market, in particular the grain traders, adjusted the cost of grain logistics, and the increased transportation costs negatively affected the economic situation of agricultural producers (because of reducing the purchase prices).

In our opinion, the solution of the above problems is possible in the following ways:

- the reformation of Ukrzaliznytsia (JSC "Ukrainian Railways"). Its position as a natural monopolist lets it overestimate the prices of services, which are often of a dubious quality. It happens because of a lack of investment funds. There is a need at the state level to develop measures to create real competition in the field of the railroad transportation. In particular, the investments into the 
development of a private stock of grain wagons should be encouraged by means of eliminating the tariff barriers. Thus, the current tariff policy of the state is to pay for the full cost of using the railroad by private wagons when moving with or without cargo. At the same time, the use of wagons-hoppers of Ukrzaliznytsia (JSC "Ukrainian Railways") without cargo is not charged. The difference in the cost of private carriers compared with the state carriers is 3-7 dollars/t;

- the development of perspective directions of domestic transport and logistics infrastructure, such as the road and river ones.

The automobile transport historically plays an important role in the organization of supply chains of agrarian products. Today about $36 \%$ of all volumes of grain is delivered by roads. Because of the limited volume amount of cargo, the cost of the road transportation is the highest among the alternatives. The condition and quality of the road surface in Ukraine do not allow increasing the capacity of road trains. The necessary condition for the efficient use of the automobile transport is investment in the development of the network of modern highways, for example, like in the EU countries.

In Ukraine, the river transport is not actively used $3 \%$ of the total volume of grain transportation). The explanation is:

- the underdevelopment (the actual absence) of the river cargo fleet and infrastructure;

- the high logistic costs (the cost of transportation of a ton of grain by the river transport is by $24 \%$ higher compared with the railroad). The company "Nibulon" presented a detailed report on the transportation of goods by the river transport. According to its data and according to the current legislation, the cost of transporting goods from Kremenchuk to Mykolaiv by ships under the Ukrainian flag and by the Ukrainian ship owners is $64.25 \mathrm{UAH} / \mathrm{t}$ more expensive than by a foreign fleet, which provides bunkering outside the territorial waters of Ukraine. The cost of diesel fuel outside the 12-mile zone is less by $\$ 360 / t$ than that of the domestic prices in Ukraine (Furdichko \& Khoroshchenko, 2016).

In order to use the potential possibilities of the river transport, it is necessary to adopt and implement a program for the creation of a river cargo fleet and the corresponding infrastructure at the state level, namely: clearing and deepening the channel for the passage of vessels with a greater loadcarrying capacity, reforming the navigation system in accordance with the modern standards, optimizing the work of gateways and dividing bridges, realizing the mechanisms of attraction of foreign investments, eliminating the barriers for access of foreign shipping companies to inland waters of Ukraine.

The supranational level - the world community.

The mechanism of Ukraine's representation in international organizations, in particular the WTO, needs to be improved. Today, the Permanent Mission of Ukraine to the United Nations and other international organizations in Geneva, which is subordinate to the Ministry of Foreign Affairs of Ukraine, operates. In fact, there is only one economist in the Mission who professionally deals with the work of Ukraine as a member of the WTO. Consequently, today's representation of Ukraine in the WTO is insufficient, which is reflected in the effectiveness of protecting its interests in view of the WTO membership. Therefore, it is necessary to involve a large number of highly skilled specialists in the Mission who would be responsible for such key areas as: the access to the market, the technical barriers to trade, the sanitary and phytosanitary measures, the trade issues in the field of intellectual property rights protection, etc.

The lack of qualified personnel is a cross-cutting issue for all the levels of international agrarian logistics (Furdichko \& Khoroshchenko, 2016). So, since 2007, the World Bank has started to calculate the Logistics Efficiency Index based on an analysis of the most important aspects of the current logistics environment. It includes, in particular, the criterion of competence and quality of logistics services. As of 2008, Ukraine takes up the 66th place among 160 countries, along with Serbia (the 65th place) and Egypt (the 67th place). On the basis of the above, one can state that there is an objective need for specialists in international logistics who are competent in the informational and physical processing of large volumes of orders; in assessing the risks of changing the world market situation; in the establishment of international communications; in the features of legal, customs, financial, cultural components of economic activity in different countries. It is necessary to intensify the training of specialists for work in the field of logistics services and management of supply chains:

- the departments of transport and infrastructure development at the international level, Ukraine's representative offices in international organizations - the supranational level; 
- the Ministries and departments of Ukraine (including the Ministry of Agrarian Policy and Food of Ukraine) - the macro-level; level;

- the departments of transport and infrastructure development at the regional level - the meso-

- the export-import and logistics departments of agrarian companies - the micro-level.

Authors should discuss the results and how they can be interpreted in perspective of previous studies and of the working hypotheses. The findings and their implications should be discussed in the broadest context possible. Future research directions may also be highlighted.

\section{Conclusions and suggestions}

The main factor that in the modern conditions of Ukraine determines the degree of realising the agricultural export potential is the state of the development of logistics sphere.

In the structure of the general problem of agro-logistics one can distinguish four levels: the microlevel, meso-level, macro-level, and supranational ones.

The "Bottlenecks" in the process of increasing the export potential in Ukraine are at:

- the micro-level - the availability (physical and financial one) of the capacities for storage of grain; the cost of transportation;

- the meso-level - the low investment activity in the field of logistics infrastructure development;

- the macro-level - the current state of the railroad transport system; the limited alternative transportation options.

- the supranational level - the imperfection of mechanisms of representation of Ukraine in international organizations.

The proposals for increasing the export potential of the agrarian sector in Ukraine:

- the development of container transportation sphere, that is expanding the range of subjects of both demand and supply included in the process;

- the creation of mechanisms for directing the funds of united territorial communities for the development of regional logistics infrastructure;

- the reform of Ukrzaliznytsia (JSC "Ukrainian Railways") by developing competition in this traditionally monopolistic market. We offer such a mechanism to reduce the possibility of obtaining a monopoly rent as a revision of the current tariff system in order to equalize the competitive conditions for the public and private sectors; the improvement of the system of electronic applications in order to provide opportunities for the long-term planning, as well as to reduce logistics costs; the introduction of material liability of elevators and Ukrzaliznytsia (JSC "Ukrainian Railways") for failure to fulfil their obligations;

- the development of alternative variants of supply chains by improving the infrastructure of the automobile and river transport;

- the expansion of Ukraine's representation in the world governmental and non-governmental organizations in order to protect the national trade interests;

- the formation of the system of training personnel qualified to work in the international agrarian market.

\section{Citation information}

Larina, T. F., Kravcov, A. G., Berezhnaja, N. G., Kutiya, O. V., \& Fenenko, K. A. (2019). Implementation of logistic approaches in forming the agricultural export strategy in Ukraine. Journal of Sustainable Development of Transport and Logistics, 4(1), 17-24. doi:10.14254/jsdtl.2019.4-1.2.

\section{References}

Dudar, V. (2015). The integration of the agricultural sector of Ukraine with the European Union in the context of free trade zone functioning. Bulletin of the Ternopil National Economic University, 2, 7-17. Retrieved from http://dspace.tneu.edu.ua/handle/316497/2590 
Dudar, V.T. (2017). The Improvement of economic policy and mechanisms of state regulation of agrarian sector in the context of strengthening its competitive positions. Bulletin of the Ternopil National Economic University, 1, 7-20. Retrieved from http://nbuv.gov.ua/UJRN/Vtneu_2017_1_3

Furdichko, L.Y., \& Khoroshchenko, A.V. (2016). Problems with prospects for the export of products of the agro-industrial complex of Ukraine. Socio-Economic Problems of the Modern Period of Ukraine, 3(119), 87-91.

Greenco LTD. (2017). Logistics of grain exports in Ukraine: View of the Soufflet Group. Retrieved from https://greencoltd.com.ua/index.php/en/k2-categories/item/332-logistika-eksporta-zernaukrainy-vzglyad-soufflet-group

Kapitska, K.V., \& Udovenko, V.V. (2018). Problems of exporting of agricultural products of Ukraine and agrarian aspects and development of trade zones of Ukraine. Scientific conferences. Rubric: Social. The science. Culture, Economy.

Larina, T.F. (2016). The strategic management of technical and technological updating of agrarian enterprises: Problems of theory and practice. Kharkiv: Smugast Typography LLC.

Lazareva, O.V., \& Vakar, K.V. (2019). Development of export potential agricultural sector of economy of Ukraine in globalization conditions. AgroSvit, 1-2, 3-9. doi: 10.32702/2306-6792.2019.1.3

Logistics in Ukraine (2018). How does transport logistics live in agribusiness. Retrieved from https://logistics-ukraine.com/2018/06/06/чим-живе-транспортна-логістика-в-агро/

Maslak, 0. (2016). Logistics of grain exports in Ukraine. Propositions - The main magazine on agribusiness. Retrieved from https://propozitsiya.com/logistika-eksporta-zerna-v-ukraine

Muzylyov, D., Kravcov, A., Karnayh, N., Berezhnaja, N., \& Kutiya, O. (2016). Development of a methodology for choosing conditions of interaction between harvesting and transport complexes. Eastern-European Journal of Enterprise Technologies, 2, 3(80), 11-21. doi:10.15587/17294061.2016.65670.

Petrenko, K.V., \& Davidovich, A.E. (2017). Analysis of Ukraine agri-food sector. Actual Problems of Economy and Management, 11, 1-10. Retrieved from http://ape.fmm.kpi.ua/article/viewFile/102602/97678

Radchenko, O.P., \& Shavalyuk, O.I. (2017). The perspectives and problems of development of the agricultural sector of Ukrainian economy in the conditions of integration with EU. Market Economy: Modern Theory and Practice of Management, 16:3(37), 1-9. Retrieved from http://rinek.onu.edu.ua/article/download/123718/118325

State Statistics Service of Ukraine. (2018). Crop production. Retrieved from http://www.ukrstat.gov.ua/operativ/operativ2006/sg/sg_rik/sg_u/rosl_u.html

Vojtov, V., Berezchnaja, N., Kravcov, A., \& Volkova, T. (2018). Evaluation of the Reliability of Transport Service of Logistics Chains. International Journal of Engineering \& Technology, 7(4-3), 270-274. doi: $10.14419 /$ ijet.v7i4.3.

Zinchuk, T.O. (2015). Problems of adaptation of the agrarian sector of the economy to the conditions of the EU-Ukraine Free Trade Agreement. Economy of Agroindustrial complex, 5, 79-87. Retrieved from http://nbuv.gov.ua/UJRN/E_apk_2015_5_14

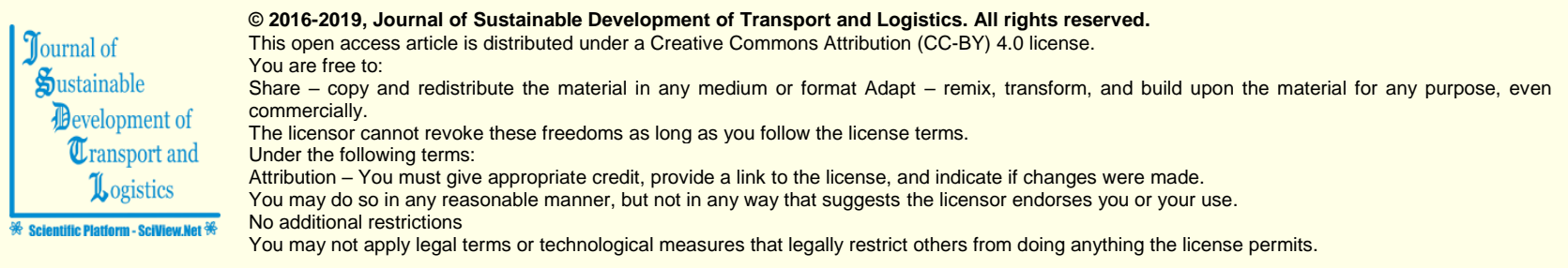

Journal of Sustainable Development of Transport and Logistics (ISSN: 2520-2979) is published by Scientific Publishing House "CSR",

Poland, EU and Scientific Publishing House "SciView", Poland, EU

Publishing with JSDTL ensures:

- Immediate, universal access to your article on publication

- High visibility and discoverability via the JSDTL website

- Rapid publication

- Guaranteed legacy preservation of your article

- Discounts and waivers for authors in developing regions

Submit your manuscript to a JSDTL at https://jsdtl.sciview.net/ or submit.jsdtl@sciview.net 